Our Nature (2005)3:50-55

\title{
Contribution to the Algal Flora (Chlorophyceae) of Namchi, Sikkim-Himalayas
}

\author{
S. Kumar and S.K. Rai ${ }^{1}$ \\ Phycology Laboratory, National Botanical Research Institute, Lucknow- 226001, India \\ ${ }^{1}$ Department of Botany, P.G. Campus, Tribhuvan University, Biratnagar, Nepal \\ Email: shivarai2003@yahoo.com
}

\begin{abstract}
The present communication is a part of survey being conducted to study the fresh water algal flora of Namchi, South Sikkim. Thirteen taxa of class Chlorophyceae, which include 8 genera, 10 species and 3 varieties, were identified from 6 samples. Spirogyra nitida (Dillw.) Link, Netrium digitus (Ehr.) Itzigs. and Roth. and Scenedesmus bijugatus (Turp.) Kuetz. were the dominant green algae followed by the remaining other rare species of Scenedesmus and Staurastrum. All these taxa constitute new records for the study area.
\end{abstract}

Key words: Chlorophyceae, Fresh water algae, India, Namchi, Sikkim-Himalaya

\section{Introduction}

The contribution to the North Indian Chlorophycean flora have been made by Kant and Anand (1978), Habib (1996, 1997), Habib and Chaturvedi (1999), Singh and Gupta (2000), Suseela and Dwivedi (2001), and Misra et al. (2002, 2005). However, the morpho-taxonomic studies of Eastern Himalayan green algal flora have received very little attention (Das 1961; Santra and Adhya 1973, 1976; Alfred 1978).

Algal floral account of Sikkim Himalaya is lacking in the literature. As far as the authors are aware, few reports on fresh water algal flora of Gangtok, the capital of Sikkim are available (Prasad and khanna 1987, Prasad and Misra 1987).

The present report is a part of survey being conducted to explore the fresh water algal flora of Namchi which is situated at an altitude of $300-5,500 \mathrm{~m}$ in South Sikkim. It shows varied topography and micro-climatic conditions that provide a congenial environment for rich growth of fresh water algae. During the multidisciplinary expedition of Sikkim Himalayas, the present survey was carried out at Namchi and its surrounding areas of different environments.

\section{Materials and Methods}

Fresh water algal samples were collected in the month of April 2001 from several localities in and around Namchi of South Sikkim. These samples were preserved in $4 \%$ formaline and deposited at Phycology laboratory of National Botanical Research Institute, Lucknow. During microscopic observations, camera lucida diagrams were drawn and identified up to species level following the keys given by Prescott (1951), Tiffany and Britton (1952), Randhawa (1959), Philipose (1967), Prasad and Misra (1992), Kant and Gupta (1998) etc. The result of morphotaxonomic studies, with description of each taxon, their collection number and locality and date of collection were given.

\section{Systematic Description}

1. Scenedesmus arcuatus Lemm. (Fig. 6)

Cells $12-13.5 \mu \mathrm{m}$ long, $6-6.2 \mu \mathrm{m}$ broad, ovoid or 
S. Kumar and S. K. Rai / Our Nature (2005)3:50-55

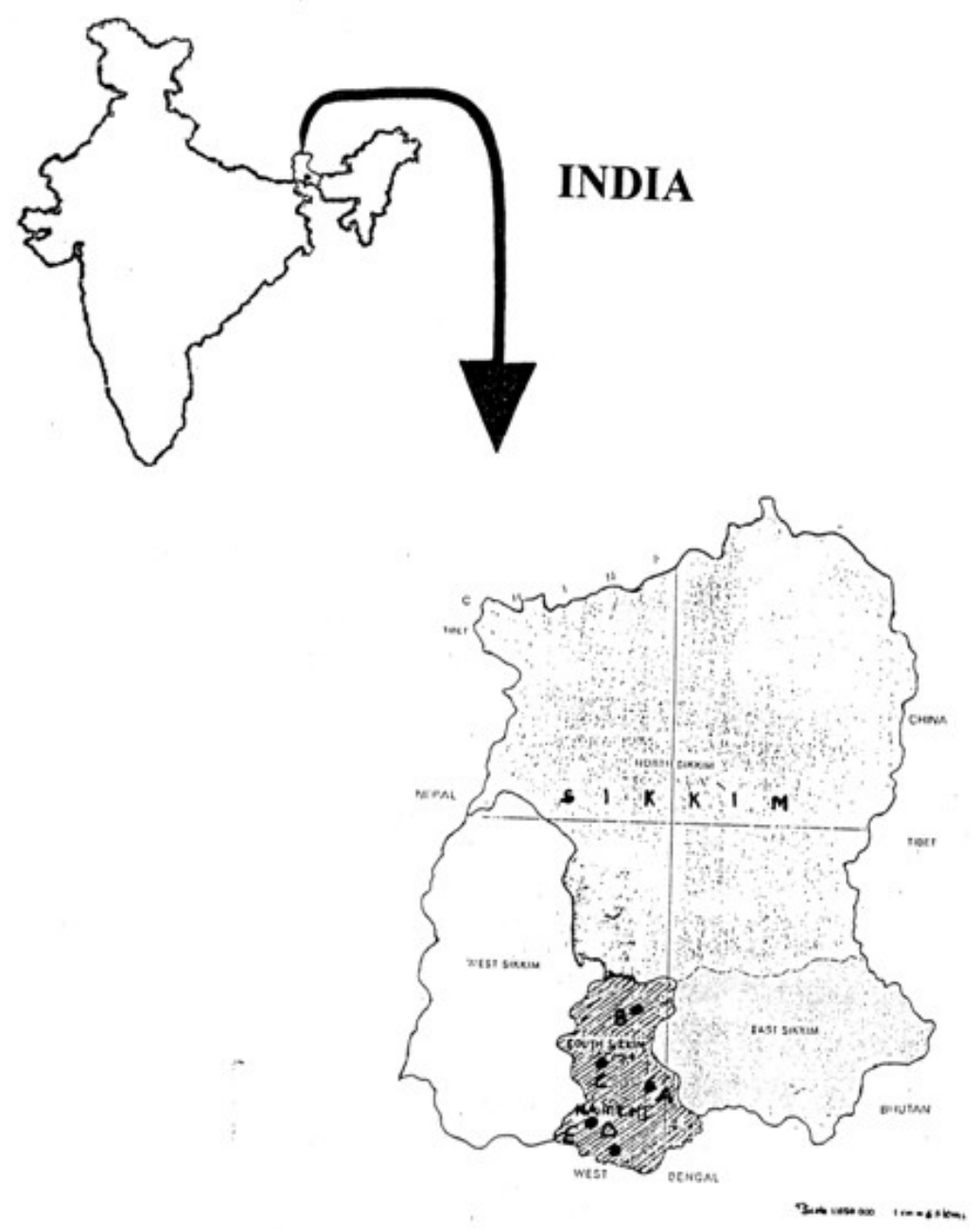

Map of Sikkim showing study area Namchi 
S. Kumar and S. K. Rai / Our Nature (2005)3:50-55
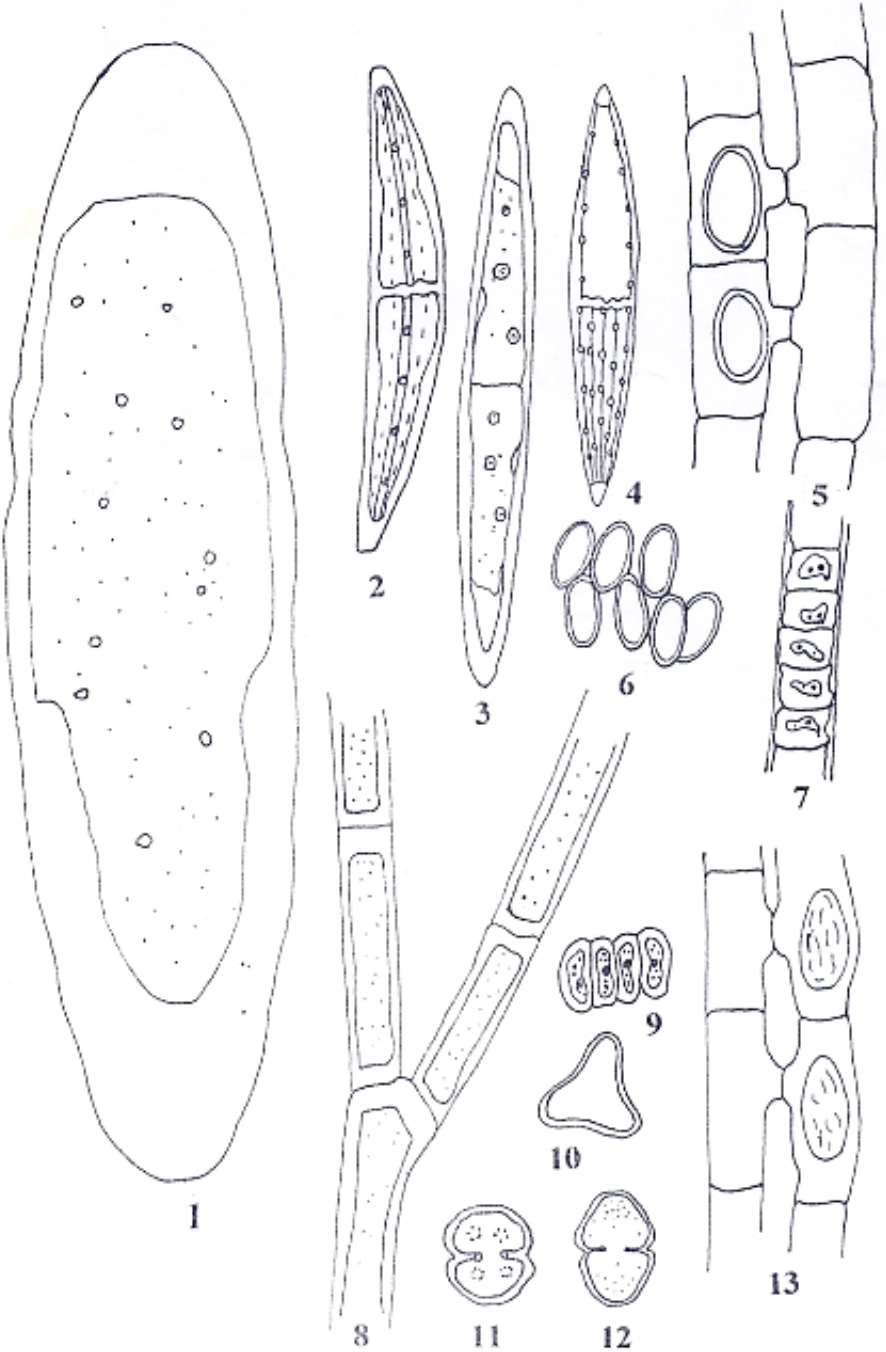

13

Figures: 1. Netrium digitus (Ehr.) Itzigs. and Roth. 2. Closterium tumidum Johns. 3. Closterium acerosum Ehr. var. elongatum Breb. 4. Closterium lunula var. massartii (Muell.) Nitzs. 5. Spirogyra nitida (Dillw.) Link 6. Scenedesmus arcuatus Lemm. 7. Ulothrix zonata (Web. and Moh.) Kuetz. 8. Cladophora glomerata (Linn.) Kuetz. 9. Scenedesmus bijugatus (Turp.) Kuetz. 10. Staurastrum pachyrhynchum Nordst. 11. Cosmarium lundellii Delp. var. ellipticum West and West 12. Cosmarium pseudogranatum var. rotundatum (Krieg.) Messik. 13. Spirogyra rhizobrachialis Jao 
S. Kumar and S. K. Rai / Our Nature (2005)3:50-55

angular, arranged in a double row, forming a curved coenobium with small interstices between cells; cell wall smooth, without spines.

Location: Waterfall at Namchi towards Namthang. Collection number: NBRI-ALSN 0189.

2. Scenedesmus bijugatus (Turp.) Kuetz. (Fig. 9) Colonies slightly curved, 2-4 cells arranged in a single linear series; cells $12.5 \mu \mathrm{m}$ long, $6.8 \mu \mathrm{m}$ broad, ellipsoid to ovoid with ends broadly rounded.

Locality: A pond near Namchi towards Jorthang. Collection number: NBRI-ALSN 0185.

3. Ulothrix zonata (Web. and Moh.) Kuetz. (Fig. 7) Vegetative cells $43.8 \mu \mathrm{m}$ long, $46.9 \mu \mathrm{m}$ broad, cylindrical or slightly swollen; cell wall thick; chloroplast band shaped, covering mid region with several pyrenoids.

Locality: Water springs at Namchi.

Collection number: NBRI-ALSN 0186.

4. Cladophora glomerata (Linn.) Kuetz. (Fig. 8) Filaments usually with profuse, y-shaped lateral branching; vegetative cells of main axis $175 \mu \mathrm{m}$ long, $45 \mu \mathrm{m}$ broad and of branchlets $180.5 \mu \mathrm{m}$ long, $35.8 \mu \mathrm{m}$ broad with thick stratified walls, multinucleate; plant mass light green.

Locality: A pond near Namchi towards Jorthang. Collection number: NBRI-ALSN 0185.

\section{Spirogyra nitida (Dillw.) Link (Fig. 5)}

Vegetative cells 110-150 $\mu \mathrm{m}$ long, $65 \mu \mathrm{m}$ broad with plane end walls; chloroplasts 4 with 3-5 turns; conjugation scalariform, tubes formed by both gametangia; zygospores 75 $\mu \mathrm{m}$ long, $45-48 \mu \mathrm{m}$ broad, cylindric ellipsoid with sharply rounded poles; spore wall smooth, minutely grooved.

Locality: Under a cliff with dripping water at Namchi.

Collection number: NBRI-ALSN 0187.

\section{Spirogyra rhizobrachialis Jao (Fig. 13)}

Vegetative cells $120-132.5 \mu \mathrm{m}$ long, $46.5 \mu \mathrm{m}$ broad with plane end walls; chloroplast 4 , slightly spiraled, deeply toothed on the margins, making 3-6 turns; conjugation scalariform, tubes formed by both gametangia; zygospores 75-80 $\mu \mathrm{m}$ long, 38-40 $\mu \mathrm{m}$ broad, ellipsoid; spore wall irregularly and coarsely reticulate, brown.

Locality: Under a cliff with dripping water at Namchi.

Collection number: NBRI-ALSN 0187.

7. Netrium digitus (Ehr.) Itzigs. and Roth. (Fig. 1)

Cells 196-197.2 $\mu \mathrm{m}$ long, $48.5 \mu \mathrm{m}$ broad, fusiform without median constriction; cell wall smooth without pores, margin convex, attenuated gradually from the middle to truncate apices; apices $32.8 \mu \mathrm{m}$ wide; chloroplast with longitudinal ridges with serrated margin.

Locality: Water spring at Namchi.

Collection number: NBRI-ALSN 0186.

Remark: The specimen observed here was similar to Tiffany and Britton (1952) but wider than the specimen described by Prasad and Misra (1992) from Andaman and Nicobar Islands (Cells 41-44.5 $\mu \mathrm{m}$ broad and apices 15$16.5 \mu \mathrm{m})$.

8. Closterium acerosum Ehr. var. elongatum Breb. (Fig. 3)

Cells $455-460 \mu \mathrm{m}$ long, $50 \mu \mathrm{m}$ broad, slightly curved, narrowly fusiform with outer margin slightly curved and inner margin almost straight, gradually tapering to the narrow and often slightly thickened, rounded truncate apices, apex $4 \mu \mathrm{m}$ wide; cell wall smooth, colourless with or without a median girdle; chloroplast without ridges, pyrenoids 3-4 in a median series.

Locality: Water springs at Namchi.

Collection number: NBRI-ALSN 0186. 
Remark: The dimensions of the present specimen differ from Prasad and Misra (1992) described from Andaman and Nicobar Islands (Cells 750-870 $\mu \mathrm{m}$ long, 37-41.5 $\mu \mathrm{m}$ broad).

9. Closterium lunula var. massartii (Muell.) Nitzs. (Fig. 4)

Cells $335 \mu \mathrm{m}$ long, $50 \mu \mathrm{m}$ broad, about 5-6 times longer than broad, almost straight, outer margin more or less curved, inner margin slightly tumid in the middle, gradually and gently attenuated to slightly truncate apices, apex $15 \mu \mathrm{m}$ wide; cell wall smooth; chloroplast with 5 ridges and numerous scattered pyrenoids.

Locality: Waterfall at Namchi towards Namthang.

Collection number: NBRI-ALSN 0188.

Remark: The present specimen is much shorter than the Prasad and Misra (1992) specimen described from Andaman and Nicobar Islands (cells $738 \mu \mathrm{m}$ long, $109 \mu \mathrm{m}$ broad).

10. Closterium tumidum Johns. (Fig. 2)

Cells $84 \mu \mathrm{m}$ long, $13.5 \mu \mathrm{m}$ broad, curved, gradually attenuated towards slightly truncate rounded apices, apex 3-4 $\mu \mathrm{m}$ wide; cell wall smooth; chloroplast with 4 ridges and 3-4 pyrenoids arranged in a row.

Locality: A pond near Namchi towards Jorthang.

Collection number: NBRI-ALSN 0185.

11. Cosmarium lundellii Delp. var. ellipticum West and West (Fig. 11)

Cells $70 \mu \mathrm{m}$ long, 50-52 $\mu \mathrm{m}$ broad, deeply constricted with linear sinus; semicells subsemicircular to sub-pyramidate with rounded angles; isthmus $8 \mu \mathrm{m}$ wide; cell wall coarsely punctuate; chloroplast axile with two pyrenoids in each semicell.

Locality: Waterfall at Namchi towards Namthang.
Collection number: NBRI-ALSN 0189.

Remark: The present specimen is larger than the specimen described by Kant and Gupta (1998) from Ladakh (Cells 51-54 $\mu \mathrm{m}$ long, 43-45 $\mu \mathrm{m}$ broad) but its isthmus is much narrower (Isthmus 15-16 $\mu \mathrm{m}$ wide).

12. Cosmarium pseudogranatum var. rotundatum (Krieg.) Messik. (Fig. 12)

Cells $21.2 \mu \mathrm{m}$ long, $16.5 \mu \mathrm{m}$ broad; semicells broadly truncate exhibiting rather prominently convex side and truncate-rounded apex; cell wall minutely punctate; isthmus $4 \mu \mathrm{m}$ wide.

Locality: Natural stream at Namchi.

Collection number: NBRI-ALSN 0190.

13. Staurastrum pachyrhynchum Nordst. (Fig. 10)

Cells $16.8 \mu \mathrm{m}$ long, $15.2 \mu \mathrm{m}$ broad, deeply constricted, sinus open and acute angled; semicells sub-elliptic, dorsal marging strongly convex, thickened angles, obtusely rounded and produced with a faint upward tilt; top view triangular showing convex sides; cell wall smooth.

Locality: Natural stream at Namchi.

Collection number: NBRI-ALSN 0190.

\section{Results and Discussion}

Namchi district of South Sikkim Himalaya falls under the tropical to subtropical hilly region. Due to low land area water stagnation is a common phenomenon, which supports the luxuriant growth of algae. Out of 13 taxa of class Chlorophyceae, 3 species of Closterium, 2 species of Cosmarium, Scenedesmus and Spirogyra (with fertile parts), and 2 species each of Netrium, Ulothrix, Cladophora and Staurastrum have been reported in this communication. Morpho-taxonomic variation was observed in the Sikkim Himalayan algal flora with that of rest part of Indian algal flora. This variation 
S. Kumar and S. K. Rai / Our Nature (2005)3:50-55

may be due to the high altitude, low temperature and other climatic and ecological conditions of the locality.

\section{Acknowledgements}

The authors express a deep gratitude to the Director, National Botanical Research Institute, Lucknow and the Head of Botany Department, Lucknow University, Lucknow for their constant encouragement and support to carry out this work.

\section{References}

Alfred, J.R.B. 1978. Algal flora of Shillong. I- Chlorophyceae. Phykos 17(1-2): 33-34.

Das, C.R. 1961. A new report on Spirogyra rugulosa Iwanoff from Senchal lake, Darjeeling, India. Bull. Bot. Surv. India 3(3/4): 389.

Habib, I. 1996. Desmids of Shimla, Himanchal Pradesh. Acta Bot. Ind. 24(1): 119.

Habib, I. 1997. Some Chlorococcales from Kotdwara, Garhwal, India. New Botanist 24: 120-128.

Habib, I. and U.K. Chaturvedi 1999. A systematic account of Chlorococcales from Ramnagar, Kumaun Himalaya. Phykos 38(1-2): 97-100.

Kant, S. and P. Gupta 1998. Algal flora of Ladakh. J. Econ. Taxon. Bot., Jodhpur. 341 p.

Kant, S. and V.K. Anand 1978. New records of Scenedesmus sp. from Jammu. Phykos 17: 81-85.

Misra, P.K., A.K. Srivastava and J. Prakash 2002. Morphotaxonomy survey on Ulotrichales and Cladophorales of North-Eastern Uttar Pradesh, India. J. Ind. bot. Soc.
81(3-4): 345-350.

Misra, P.K., A.K. Srivastava, J. Prakash and S.K. Rai 2005. Some fresh water filamentous chlorophycean algae from district Balrampur, Uttar Pradesh, India. Eco. Env. and Cons. 11(3-4): 429-431.

Philipose, M.T. 1967. Chlorococcales, I.C.A.R. monograph on algae, New Delhi. 365p.

Prasad, B.N. and P. Khanna 1987. The Cyanophycean flora of Sikkim- I. Oscillatoriaceae. J. Ind. bot. Soc. 66: 253-260.

Prasad, B.N. and P.K. Misra 1992. Fresh water algal flora of Andaman and Nicobar Islands, Vol. II. B. Singh and M.P. Singh, Dehradun, India. 284 p.

Prasad, B.N. and R. Misra 1987. Desmid flora of Sikkim- I. Geophytology 17(2): 163-173.

Prescott, G.W. 1951. Algae of the Western great lakes area. WM.C. Brown Publishers, Dubuque, Iowa. 977p.

Randhawa, M.S. 1959. Zygnemaceae. I.C.A.R. monograph on algae, New Delhi. 478p.

Santra, S.C. and T.K. Adhya 1973. Zygnemataceae of Eastern Himalaya. I- Spirogyra Link. Bull. Bot. Surv. India 15(34): 281.

Santra, S.C. and T.K. Adhya 1976. Zygnemataceae of Eastern Himalaya. II- Spirogyra Link. Bull. Bot. Surv. India 30: 47-49.

Singh, K.P. and R.K. Gupta 2000. A note on the algae from Apatani valley, Arunanchal Pradesh, India. Ann. For. 8(1): $38-44$.

Suseela, M.R. and S. Dwivedi 2001. A contribution to fresh water algal flora of Bundelkhand region of U.P. (Chlorophyceae and Xanthophyceae). Phytotaxonomy 1: 76-81.

Tiffany, L.H. and M.E. Britton 1952. The algae of Illinois. Hafner Publishing Co., New York. 407p. 